\title{
The influence of climate and hydrological variables on opposite anomaly in active-layer thickness between Eurasian and North American watersheds
}

\author{
H. Park ${ }^{1}$, J. Walsh ${ }^{2}$, A. N. Fedorov ${ }^{3}$, A. B. Sherstiukov ${ }^{4}$, Y. Iijima ${ }^{1}$, and T. Ohata ${ }^{1}$ \\ ${ }^{1}$ Research Institute for Global Change, JAMSTEC, Yokosuka, Japan \\ ${ }^{2}$ International Arctic Research Center, University of Alaska Fairbanks, Fairbanks, AK 99775, USA \\ ${ }^{3}$ Melnikov Permafrost Institute, SB RAS, Yakutsk, Russia \\ ${ }^{4}$ All-Russian Research Institute of Hydrometeorological Information - World Data Centre, Obninsk, Russia \\ Correspondence to: H. Park (park@jamstec.go.jp)
}

Received: 14 June 2012 - Published in The Cryosphere Discuss.: 17 July 2012

Revised: 1 March 2013 - Accepted: 10 March 2013 - Published: 4 April 2013

\begin{abstract}
This study not only examined the spatiotemporal variations of active-layer thickness (ALT) in permafrost regions during 1948-2006 over the terrestrial Arctic regions experiencing climate changes, but also identified the associated drivers based on observational data and a simulation conducted by a land surface model (CHANGE). The focus on the ALT extends previous studies that have emphasized ground temperatures in permafrost regions. The $\mathrm{Ob}$, Yenisey, Lena, Yukon, and Mackenzie watersheds are foci of the study. Time series of ALT in Eurasian watersheds showed generally increasing trends, while the increase in ALT in North American watersheds was not significant. However, ALT in the North American watersheds has been negatively anomalous since 1990 when the Arctic air temperature entered into a warming phase. The warming temperatures were not simply expressed to increases in ALT. Since 1990 when the warming increased, the forcing of the ALT by the higher annual thawing index (ATI) in the Mackenzie and Yukon basins has been offset by the combined effects of less insulation caused by thinner snow depth and drier soil during summer. In contrast, the increasing ATI together with thicker snow depth and higher summer soil moisture in the Lena contributed to the increase in ALT. The results imply that the soil thermal and moisture regimes formed in the prethaw season(s) provide memory that manifests itself during the summer. The different ALT anomalies between Eurasian and North American watersheds highlight increased importance of the variability of hydrological variables.
\end{abstract}

\section{Introduction}

Permafrost is considered vulnerable to increasing temperatures, and its degradation has the potential to initiate numerous feedbacks, predominantly positive, in the Arctic and global climate system (McGuire et al., 2006). Air temperatures over the Arctic land areas have indeed increased considerably over the last few decades (Chapman and Walsh, 2007; Bekryaev et al., 2010). Most general circulation models project that the warming will continue (IPCC, 2008), increasing the risk of permafrost degradation. It is therefore important to elucidate how soil temperatures are rising, how permafrost is degrading, and the relationships between the two.

Permafrost is also a useful climate indicator because it integrates processes (e.g., air temperature, precipitation, snow, and vegetation) that occur at and above the ground surface. Experiments with temperature warming scenarios have projected poleward shifts in permafrost boundaries relative to the current distribution of permafrost (Chen et al., 2003; Lawrence et al., 2008). Anisimov and Nelson (1997) simulated the changes in active-layer thickness (ALT) in the Northern Hemisphere under climate change scenarios and evaluated the risk of ground subsidence in the circum-Arctic permafrost region. Oelke et al. (2004) simulated the increasing trends in soil temperature and ALT in the Arctic permafrost regions during 1980-2002.

The changes in ALT have also been monitored by in situ observations (Brown et al., 2000). The active layer in Russia 
exhibited a statistically significant deepening by approximately $20 \mathrm{~cm}$ over the period of 1956-1990 (Frauenfeld et al., 2004). Zhang et al. (2001) analyzed long-term changes from the 1890s to 1990s in soil temperatures at Irkutsk, Russia, finding that soil temperature at $40 \mathrm{~cm}$ depth increased by up to $9^{\circ} \mathrm{C}$ during the winter. Permafrost surface temperatures in northern Alaska have increased by $2-4^{\circ} \mathrm{C}$ in the 20th century (Lachenbruch and Marshall, 1986). A warming trend in soil temperature was also found at climate stations across Canada during the 20th century (Chen et al., 2003; Zhang et al., 2005; Smith et al., 2010; Qian et al., 2011).

Consistent with these changes of soil temperatre, surface air temperature (SAT) at high-latitude $\left(>60^{\circ} \mathrm{N}\right)$ meteorological land stations warmed by $1.36^{\circ} \mathrm{C}$ during $1875-2008$ (Bekryaev et al., 2010). On a regional basis, atmospheric warming and its implications for soil temperature and ALT have been examined for Eurasia (Frauenfeld et al., 2004) and North America (Romanovsky et al., 2010; Smith et al., 2010). Soil thermal states depend on a number of complex interactions between soil, vegetation, snow, and hydrology (Hinzman et al., 1995; Zhang et al., 1997). Changes in these factors can influence heat and water exchanges on the surface and in the soil, consequently modulating the relationship between air and soil temperatures. Therefore, the measured or projected warming trend in SAT cannot necessarily be simply applied to soil temperature and ALT.

A number of studies have demonstrated that change in snow depth (SND) can be as important as change in air temperature to changes in soil temperature because of the insulating effect (Stieglitz et al., 2003; Zhang, 2005). In particular, changes in accumulation, duration, timing, and amount of snow during the winter season play an important role in determining how the air temperature signal propagates into the ground (Zhang et al., 1996). Arctic warming can be expected to result in early snowmelt and late snow accumulation, and satellite observations have already detected a reduction in Arctic spring snow cover (Brown et al., 2010). Long-term changes in SND have also been found at continental scales, with increasing trends in winter SND over the Siberian regions during the last $30 \mathrm{yr}$ (Bulygina et al., 2009), while SND in North America has generally decreased since 1970 (Dyer and Monte, 2006). The opposition of SND anomalies between the two continents is supported by satellite observation (Biancamaria et al., 2011) and a model simulation (Park et al., 2011b).

Both observations and modeling suggest that soil temperature change over the Arctic since the latter part of the 20th century can be primarily attributed to air temperature and SND trends and/or variations (Stieglitz et al., 2003; Frauenfeld et al., 2004; Osterkamp, 2007). The opposing SND trends in Eurasia and North America could drive soil thermal and moisture regimes differently from the geographic pattern of temperature change. In reality, soil temperature at the Healy site of interior Alaska has responded to the decreasing SND by a decrease of ALT since the late 1990s (Osterkamp, 2007). By contrast, since 2000 the increased SND in a Siberian taiga forest has significantly contributed to an increase of ALT (Iijima et al., 2010). These site-specific results cannot reliably be extrapolated to large regions. However, the observations provide the insight that both soil temperature and ALT likely responded, at least partially, to the SND anomalies.

From an experiment that used numerical modeling and empirical equations, Zhang et al. (2005) found that ALTs at three Siberian watersheds exhibited complex and inconsistent responses to variations in snow cover during the 20th century. However, for the latter half of 20th century, snow state variations could account for as much as $50-100 \%$ of total soil temperature variations in the Arctic (Lawrence and Slater, 2010). These studies demonstrated that changes in snow can either amplify or mitigate soil warming. However, few studies have explored interactions between ALT and changes in climatic and hydrological variables at regional or continental scales in the framework provided by a comprehensive terrestrial model. In this study, we draw upon the results of a coupled hydrological and biogeochemical model (CHANGE) (Park et al., 2011a) applied to the pan-Arctic terrestrial regions at the spatial resolution of $0.5^{\circ}$ latitude/longitude over the period of 1948-2006. We not only delineate the characteristics of the ALT anomaly at the watershed scale, but also identify the across-region relationships and anomalies of associated drivers. Thus this study is directed at a more comprehensive understanding for the spatiotemporal variations of ALT in the major Arctic watersheds. In addition, the simulated soil temperature and ALT are validated by available observations.

\section{Descriptions of model and data}

\subsection{Land surface model, CHANGE}

The CHANGE model is a physically based land surface model designed to integrate interactions and feedbacks in a soil/vegetation/atmosphere system in the Arctic terrestrial regions. CHANGE consists of four modules: a land surface module, a vegetation phenology module, a carbon and nitrogen balance module, and a vegetation dynamic module. The full description of CHANGE is given by Park et al. (2011a), but both the land surface module and the recent revision are summarized here.

The land surface module essentially solves an energy and mass balance for the canopy and snow/soil surfaces over a gridded domain. Each soil layer is characterized by three prognostic variables: temperature, liquid water content, and ice content, which are closely connected to radiation, energy, and water budgets of the canopy and snow. The soil heat balance equation including the water phase change is given by 
$C_{\mathrm{s}} \frac{\partial T}{\partial t}=\frac{\partial}{\partial z}\left[k \frac{\partial T}{\partial z}\right]+\rho_{\text {ice }} \lambda_{\mathrm{f}}\left[\frac{\partial \theta_{\text {ice }}}{\partial t}\right]$

where $C_{\mathrm{s}}$ is the soil volumetric heat capacity, $T$ is the soil temperature, $k$ is the soil thermal conductivity, $\rho_{\text {ice }}$ is the density of ice, $\lambda_{\mathrm{f}}$ is the latent heat of fusion, $\theta_{\text {ice }}$ is the ice content of the layer, and $z$ is the depth. The model simulates the dynamics of soil heat by an exponential multilayer profile (i.e., 15 layers) with the upper boundary conditions determined from the energy balance and the bottom boundary conditions (at $30.5 \mathrm{~m}$ depth) defined as zero heat flux. At each time step, the thermal fluxes through the soil column are first solved. The estimated soil layer temperatures are then used to predict $\theta_{\text {ice }}$. The updated $\theta_{\text {ice }}$ with liquid moisture content in unfrozen soil estimates the matric potential in frozen soil, and the soil thermal properties for the next time step are then reconstructed from the updated ice and liquid water content. The soil thermal and hydraulic properties for each grid box are parameterized in terms of the soil texture, e.g. the sand and clay content, and the amount of soil organic matter. The soil organic matter is dynamic, changing with time in response to the model's carbon budget. The estimated carbon content for each grid cell is vertically distributed in the upper $1.8 \mathrm{~m}$ through the soil column according to rules related to ecosystem type. The grid cell with high organic soil content (e.g., $>40 \mathrm{~kg} \mathrm{~m}^{-2}$ ) has a higher organic layer of roughly $1-30 \mathrm{~cm}$ depth, and the organic content of the underlying layers sharply decreases with depth (Lawrence et al., 2008).

The depth of the bottom boundary condition can be important in the simulation of soil temperature because it strongly influences seasonal and interannual dynamics. In the old version of CHANGE, the soil bottom boundary condition was set to $10.5 \mathrm{~m}$. Recent studies suggested that soil columns deeper than $30 \mathrm{~m}$ are needed to simulate accurately the annual cycle and decadal trends of subsurface temperatures, especially trends associated with climate change (Smerdon and Stieglitz, 2006; Alexeev et al., 2007; Stevens et al., 2007). Mölders and Romanovsky (2006) noted that the soil column depth should exceed the depth of seasonal changes in soil temperature and moisture states, which can be as deep as 15-20 m (Romanovsky and Osterkamp, 1997). On the basis of these recommendations, we tested CHANGE with soil depths ranging from 30 to $50 \mathrm{~m}$ at a single point and assessed how the depth of the column might impact soil temperatures. The depth of the column beyond $30 \mathrm{~m}$ did not have a strong influence on the results (Lawrence et al., 2008), although the soil temperature rise in the near-surface layers was slightly slower with a $50 \mathrm{~m}$ column compared to $30 \mathrm{~m}$. Therefore, we set the column depth to $30.5 \mathrm{~m}$. The deep ground is generally fractured bedrock. However, CHANGE does not include the representation of the deep soil/rock column. For simplicity, the layers deeper than $5.5 \mathrm{~m}$ are assumed to be hydrologically inactive; water cannot pass into or out of that depth. This treatment is primarily applied to non-permafrost grid boxes, because the parameterization of ice blocking of water flow effectively limits liquid flow in permafrost soil layers.

Because snowpacks are naturally layered media, CHANGE represent the snowpack by two layers: a surface layer and an underlying deeper layer containing most of the snowpack. The surface layer is used to solve the surface energy balance, while the underlying layer is used to simulate fluxes through deeper snowpacks. The surface energy balance components are used to simulate snowmelt, refreezing, and changes in the snowpack heat content. The mass balance components represent snow accumulation/ablation, changes in snow water equivalent, and water yield from the snowpack. Snow density varies with compaction caused by metamorphism and overburden. The thickness of snowpack is estimated based on the calculated snow density and snow water equivalent. Albedo from the canopy and ground surfaces is calculated using the two-stream approximation (Meador and Weaver, 1980); the overall direct beam and diffuse ground albedos are weighted using combinations of soil and snow albedos. The latter is estimated by considering the effects of solar zenith angle and snow age that is calculated from the history of snow accumulation and melt.

The main structure of carbon and nitrogen cycling in CHANGE is based on the ecosystem process model BIOME-BGC (Thornton et al., 2002). The carbon absorbed through photosynthesis is partitioned into leaves, stems, fine roots, and coarse roots. The root carbon amounts are used to estimate the dynamical root profile in the soil layers. The estimated root profile is combined with the estimate of soil water stress, which is in turn fed back to photosynthesis and stomatal conductance. Soil organic matter affects the dynamics of soil water and temperature (as noted above), which in turn impacts the decomposition rate of soil organic matter. The dynamics of soil water and temperature are intertwined with the biogeochemical cycles and vegetation dynamics, which in turn are coupled to the behavior of leaf phenology. The dynamic vegetation model, which explicitly couples plant growth to the land surface module, facilitates the exploration of the interactions between vegetation and land surface processes and between vegetation and climate.

\subsection{Input data}

Inputs to the model include information about vegetation type, soil texture, and atmospheric climate. Vegetation type in each grid box is determined based on the vegetation map given by Ramankutty and Foley (1999), in which there are 15 types. Among them, ice cover is not considered in this simulation and thus Greenland is not included. CHANGE also requires soil texture information in terms of fraction of sand, silt, and clay: we use the data derived from the IGBP SoilData System (Global Soil Data Task, 2000). The texture fraction is used to estimate soil thermal conductivity, heat 


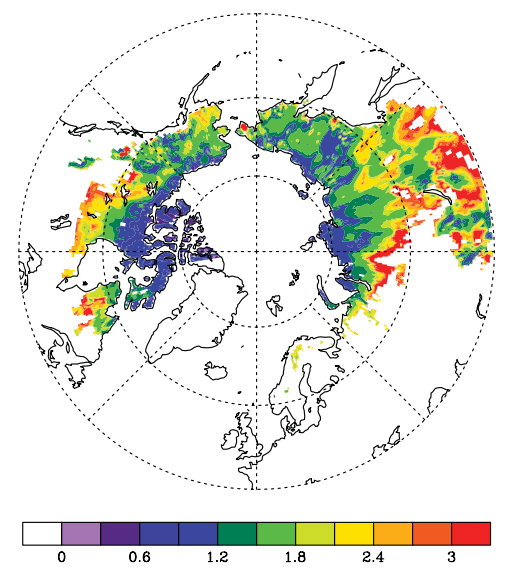

(b)

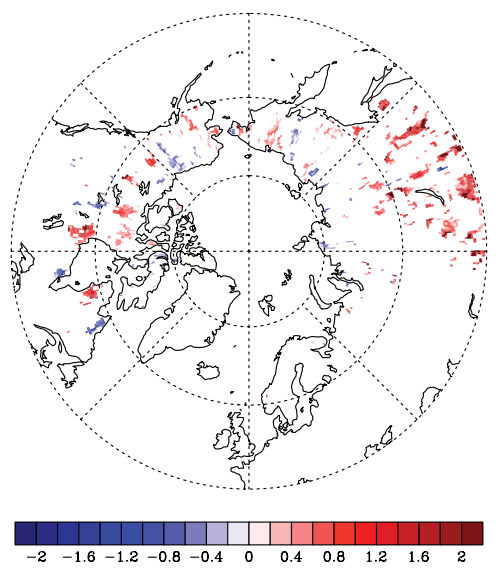

(c)

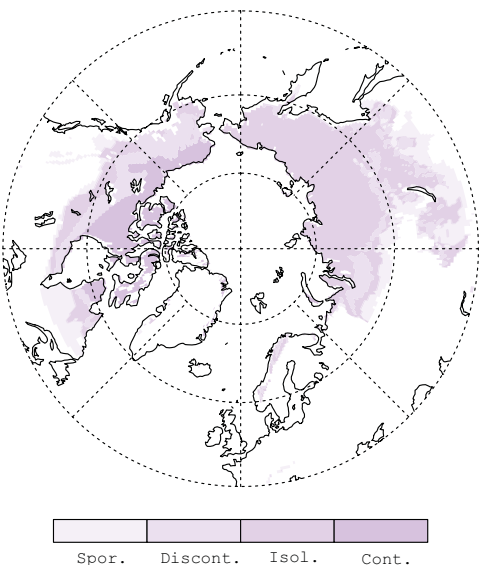

Fig. 1. (a) Distribution of the simulated active-layer thickness (m) averaged over 1948-2006 and (b) the trend ( $\mathrm{cm} \mathrm{yr}^{-1}$ ) above $95 \%$ confidence level during the same period. (c) is the observed permafrost coverage as compiled by the International Permafrost Association (IPA) (Brown et al., 2001).

capacity, and hydraulic conductivity, in combination with soil organic matter simulated by the model.

The gridded climate data used in this study has a $0.5^{\circ}$ latitude/longitude spatial resolution globally and a daily temporal resolution from 1948 to 2006 (Hirabayashi et al., 2008). It includes daily air temperatures (mean, maximum, and minimum), precipitation, specific humidity, and solar radiation, constructed from meteorological station observations. These forcing data were constructed from several types of data sources (Hirabayashi et al., 2008), with different time and space scales. The details of the data sources and the disaggregation for the individual components into a daily time series, as well as their gridding processes, are described by Hirabayashi et al. (2005). However, wind speed was not included in the data set. Therefore, we computed daily means of the 6-hourly surface wind data for the period of 1958-2001 from European Centre for Medium-Range Weather Forecasts (ECMWF; ERA-40) for each day and grid cell, then interpolated the $2.5^{\circ}$ ERA-40 grids to a resolution of $0.5^{\circ}$. The daily averaged wind grids were then averaged into a seasonally varying climatology for the period 1958-2001; this climatology was used for the years for which the wind data does not exist. We downscaled this daily forcing data to hourly resolution to accommodate the time step required by CHANGE. The temporal and spatial interpolation for each variable is described by Park et al. (2011a), who found that a constant diurnal relative humidity can overestimate latent heat flux. Thus, an algorithm developed by Castelliví et al. (1996) was used to obtain a diurnal cycle of relative humidity.

\subsection{Simulation design}

The ground thermal and hydrological regimes as well as the vegetation components for each grid box must be initialized.
Since there are no detailed measurements for model initialization, the initial conditions were determined by a spin-up running from an assumed first-day state of no snow and no soil carbon, and a very small initial vegetation carbon. The initial soil moisture (SM) was set to the field capacity of the soil type for the top $5.5 \mathrm{~m}$ depth, and to $90 \%$ of saturation for the remaining deeper layers, and the soil temperature was also exponentially interpolated using air temperature of the start date at the surface and mean annual air temperature at the bottom layer. Through the spin-up run, a dynamic equilibrium of total ecosystem carbon is determined by the prescribed climate, repeating approximately for $420 \mathrm{yr}$ with the forcing data of the initial $20 \mathrm{yr}$ and a pre-industrial $\mathrm{CO}_{2}$ concentration of $300 \mathrm{ppm}$. The influences of the initial conditions on the soil processes become negligible by the end of the spin-up.

The dynamic ecosystem process model Biome-BGC, included in CHANGE, needs a number of parameters. Previously examined parameters (White et al., 2000) are prescribed for individual vegetation types. With these parameters, CHANGE simulates energy, water, and $\mathrm{CO}_{2}$ fluxes for the years 1948-2006 with dynamic vegetation.

\section{Results}

\subsection{Comparison between simulation and observation}

\subsubsection{Permafrost extent}

Figure 1 is a comparison of the simulated permafrost extent against the permafrost map produced by the International Permafrost Association (IPA) (Brown et al., 2001). We define permafrost extent as the integrated area in which ground remains below $0^{\circ} \mathrm{C}$ for two or more consecutive years in at 
least one soil layer among the 15 soil layers. The simulated total permafrost extent at $>45^{\circ} \mathrm{N}$ cannot directly compare with the permafrost extent derived from the IPA map, because Iceland and some other northern islands are excluded in this simulation. The model simulated that permafrost regions occupy approximately $17.72 \times 10^{6} \mathrm{~km}^{2}$, which is less than the $22.79 \times 10^{6} \mathrm{~km}^{2}$ in the Northern Hemisphere estimated by Zhang et al. (1999). The difference is likely due to the different two study regions. Although CHANGE tends to overestimate the permafrost at the southern boundary of Siberia, the simulation shows generally good agreement with the IPA map (Fig. 1c). IPA classifies permafrost area into four classes (continuous, discontinuous, sporadic, and isolated permafrost) with decreasing coverage. CHANGE, on the other hand, does not account for subgrid variability in soil temperature. In this respect, CHANGE simulates the potential upper limit of permafrost occurrence rather than the actual coverage that depends on sub-grid-scale variations.

Figure 1 shows the ALT distribution and the linear trend of the ALT. Although ALT exhibits large regional heterogeneity, the ALT generally deepens toward the low latitudes (Fig. 1a). The change in ALT is large at the southern boundary edge of permafrost, especially in Siberia (Fig. 1b). Meanwhile, the decrease in ALT is found in some regions of North America (Fig. 1b). The decline in Arctic summer sea ice cover increased adjacent terrestrial air temperatures (Screen and Simmonds, 2010), which contributed to soil warming. However, ALT in these regions did not linearly respond to the Arctic warming, indicating that ALT is not simply explained by the air temperature trend.

\subsubsection{Active-layer thickness}

Observations on ALT have been collected from the Circumpolar Active Layer Monitoring (CALM) since the 1990s (Brown et al., 2000), Global Terrestrial Network for Permafrost (GTN-P) in Canada, and Melnikov Permafrost Institute station data around Yakutsk, Russia. The meteorological stations in Russia have long-term records of soil temperature, from which ALT was obtained by determining the seasonal position of $0^{\circ} \mathrm{C}$ isotherm in the soil temperature profile. The simulated ALT was averaged by a distance weighting of the four grid cells closest to each CALM site, for the period overlapping with the observation. The simulated values were then plotted against the observations (Fig. 2a), which show a significant correlation $(r=0.38, p<0.0001)$. The plot shows generally good agreement between the observed and modeled ALT in the meteorological stations of Russia. Meanwhile, the largest differences are found in CALM sites. The differences are at least partially attributable to the scale mismatch between the simulations and observations, as the model run is relatively coarse scale $\left(0.5^{\circ}\right.$ latitude/longitude) while the observations are essentially at point scale. For complex terrain, point observations extrapolated to obtain largearea averages tend to be poor representations of true area means. The scale issues generally arise from differences in elevation, climate, soil properties, and landscape. The simulated ALT appears to be generally too deep compared to the observations of the CALM sites (Fig. 2a), which appear to be related to the biases of soil thermal properties and soil moisture.

\subsubsection{Soil temperature}

The preceding section focused on the validity of the simulated permafrost and ALT. A more direct comparison is possible using soil temperature observed at field sites. We used data sets of the Russian Historical Soil Temperature (available from http://nsidc.org/data/arcss078.html), Russian meteorological stations (http://meteo.ru/english/climate/soil. php), CALM sites in Mongolia, GTN-P in Canada, and borehole temperatures in Alaska (http://data.eol.ucar.edu/codiac/ dss/). Soil temperatures at individual locations were for different measuring periods, intervals (temporal resolution), and depths. Therefore, the observations were averaged for the available period at $0.8-1.2 \mathrm{~m}$ depth. The simulated soil temperature was also averaged for the period overlapping the observation. The average was distance-weighted for the grid cells surrounding the observation site. Fig. 3a shows the comparison between the observed and simulated soil temperatures, including the sites in non-permafrost regions (Fig. 3b). CHANGE simulated well the observed soil temperatures at a statistically significant level $(r=0.85, p<0.0001$, Fig. 3a). However, the simulated soil temperatures exhibit a cool bias of $-2.1{ }^{\circ} \mathrm{C}$, which is the difference between the observed and simulated averages. The cool bias has also been found in other models (Dankers et al., 2011; Lawrence et al., 2011). Lawrence et al. (2011) explained that their cool bias was related to the limitations of the soil hydrology scheme in frozen or partially frozen conditions. Moreover, as in the ALT comparison, the scale mismatch and the limited spatial coverage of observations limit the direct comparison of the modeled soil temperature to the point observation.

The underestimate in soil temperature by the model is apparent at the Russian meteorological stations (Fig. 3a). The underestimate also seems to be related partially to the difference in land surface characteristics in the model compared to the observation points. Most of the Russian meteorological stations used in Fig. 3 were established over bare land or short grass without thick soil organic layers, while the model considered grid cells surrounding the climatic stations to be forest with a thick surface organic layer. The magnitude of the response of soil temperature to climate is most likely smaller in forest than in grass, since the thick organic layer can effectively reduce the heat conductivity. The dense canopy of forest also reduces light received over forest floor, thereby resulting in cooler soil. For example, the meteorological station of Yakutsk, Russia, had an observed average temperature of $-0.01{ }^{\circ} \mathrm{C}$ at soil depth $1.2 \mathrm{~m}$ during $1998-2006$, while borehole measurements at a dense larch forest $20 \mathrm{~km}$ 
(a)

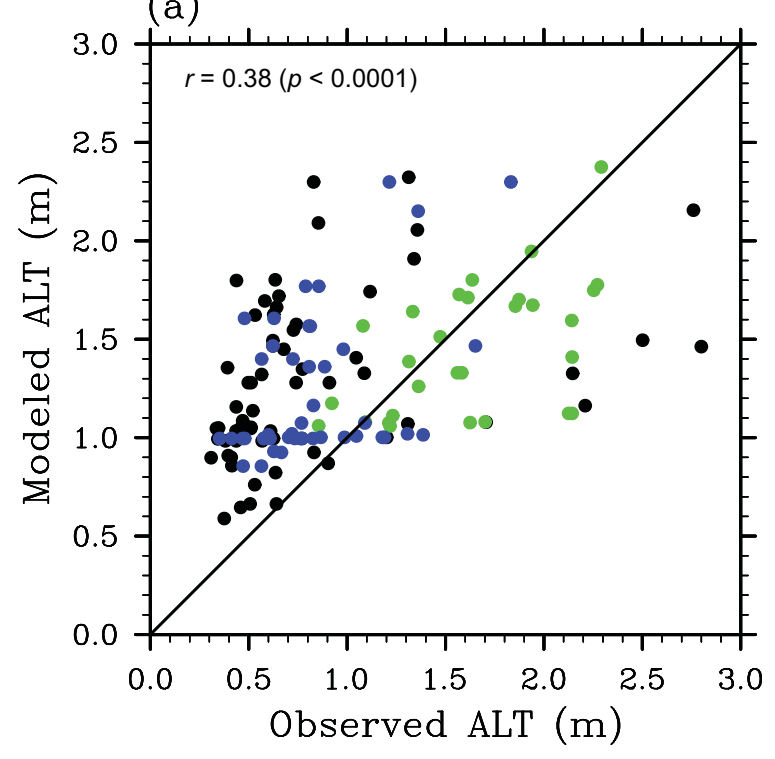

(b)

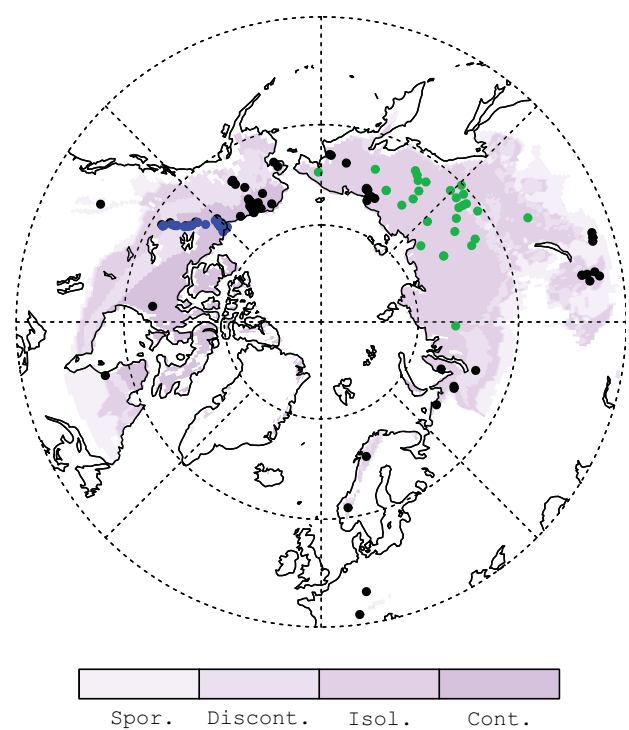

Fig. 2. (a) Scatter plot of observed and simulated (calculated from soil temperature profiles) ALT at (b) CALM (black), GTN-P (blue), and Melnikov Permafrost Institute stations (green). Model results are ensemble means for the periods coinciding with the observations.

(a)

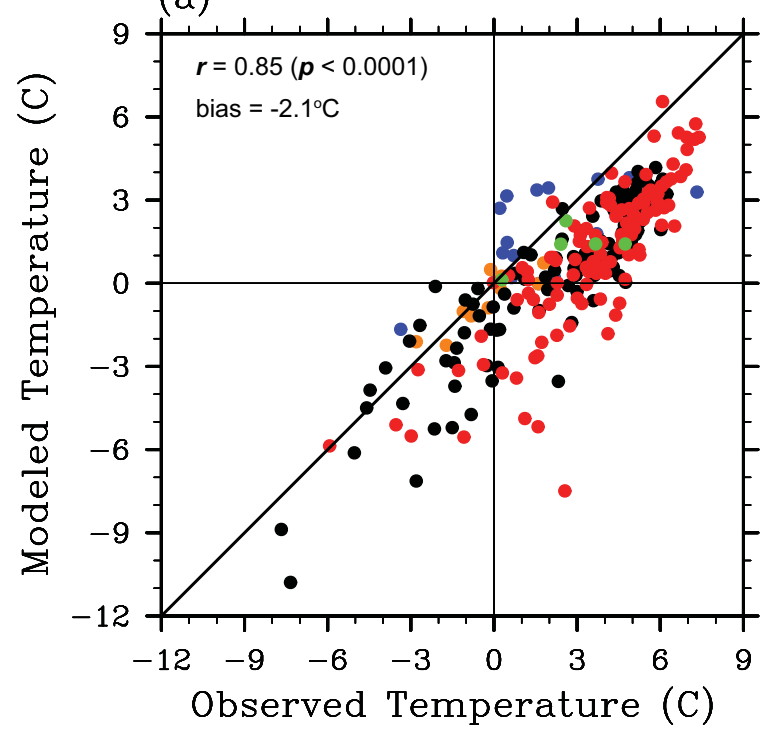

(b)

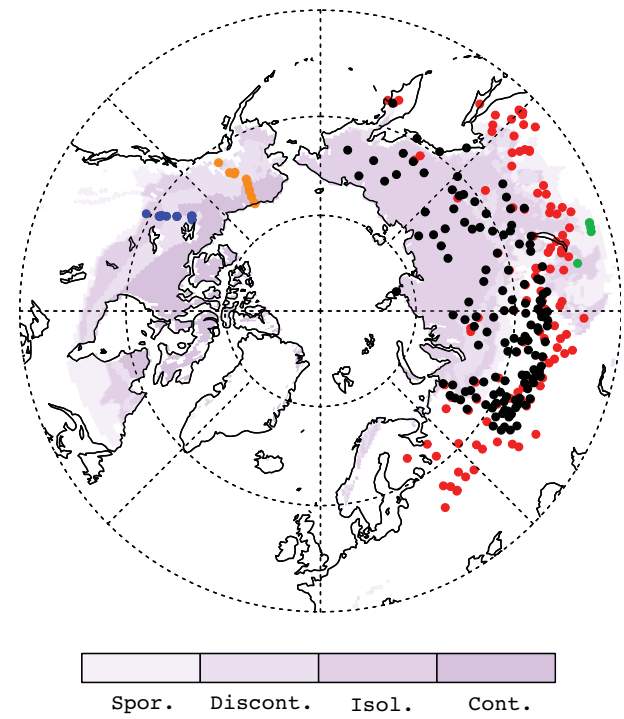

Fig. 3. (a) Scatter plot of observed and simulated soil temperature at $0.8-1.2 \mathrm{~m}$ depth for (b) Russian Historical Soil Temperature (red), Russian meteorological stations (black), GTN-P in Canada (blue), borehole temperatures in Alaska (orange), and CALM sites in Mongolia (green). Model results are ensemble means for the periods coinciding with the observations.

north from the station indicated a $-1.90^{\circ} \mathrm{C}$ soil temperature at the same soil depth during the same period. CHANGE simulated $-1.66^{\circ} \mathrm{C}$, on average, for the grid cells around the Yakutsk station.

\subsection{Spatiotemporal variations of hydro-climatological variables and ALT}

Figure 4 shows the time series of spatial distributions of decadal anomalies of the annual thawing index (ATI), averaged SND from January to March, SM, and ALT in the permafrost region. SM represents the averaged soil water for the period of June to August, less the ice amount, in the 


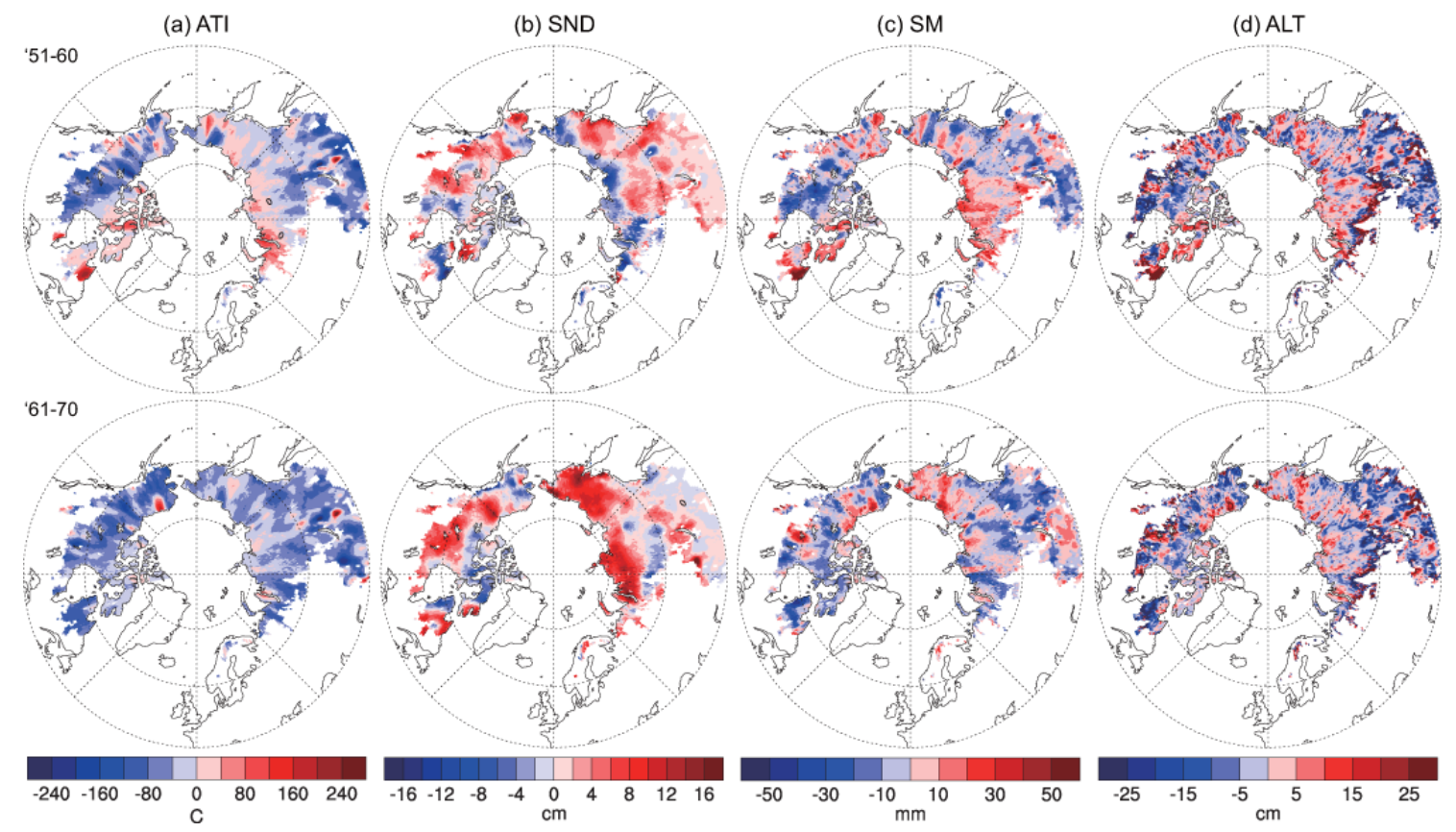

Fig. 4 Maps of decadal anomalies of annual thawing index (a), snow depth averaged during January to March (b), soil moisture averaged during June to August excluding ice amount within soil depth $1.6 \mathrm{~m}(\mathbf{c})$, and active layer depth (d).

(a) ATI
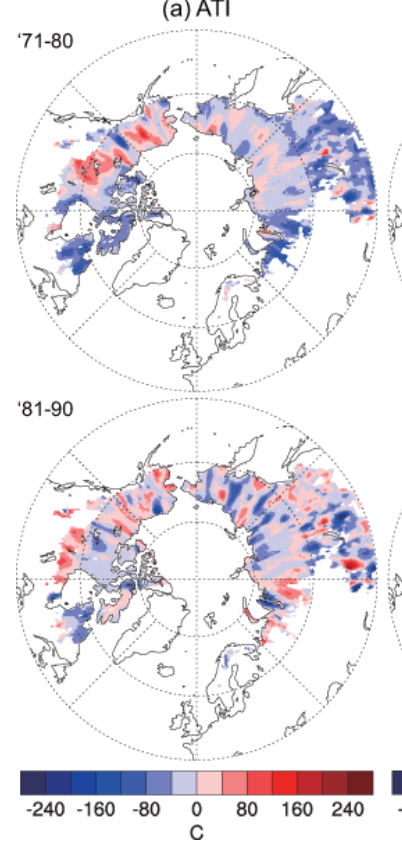

(b) SND
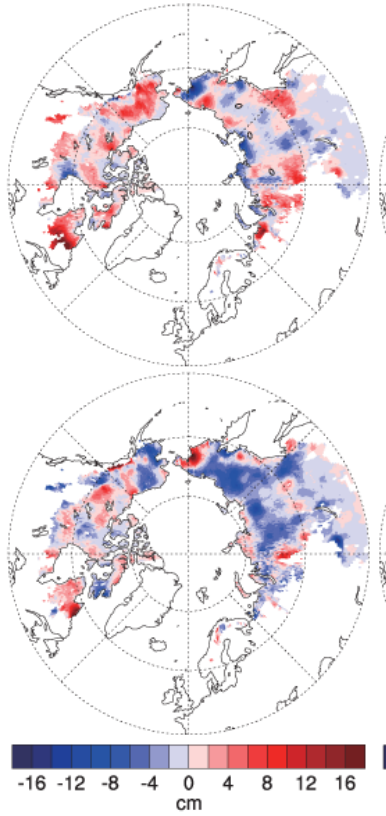

(c) SM

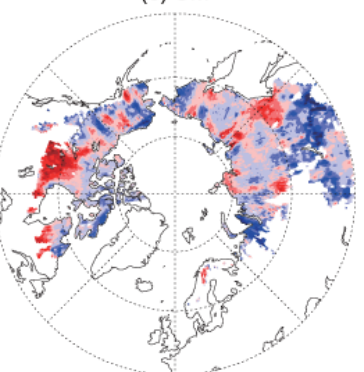

(d) ALT

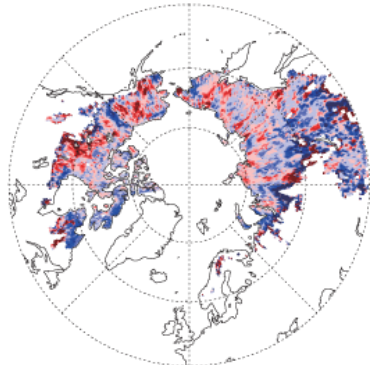

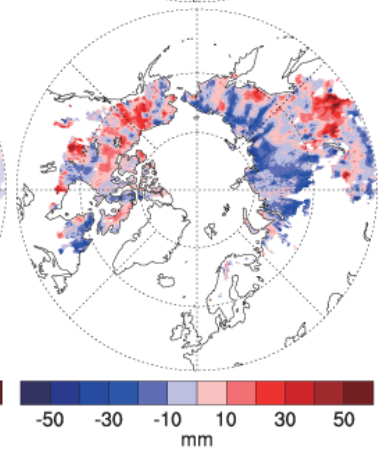

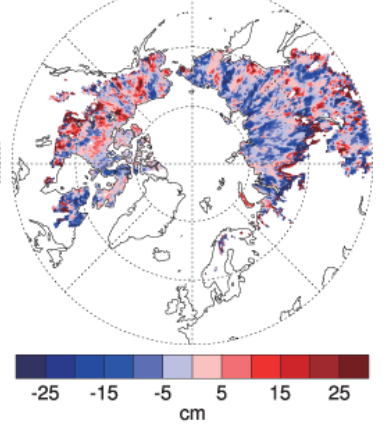

Fig. 4. Continued.

upper $1.6 \mathrm{~m}$. The ATI exhibits an increasing trend with time. The increase of the ATI is highly significant from 1991 onwards. In the period of 2001-2006, the ATI in almost all of the Eurasian region showed positive anomalies. The increase of the ATI in southern Siberia and far eastern Siberia was $200{ }^{\circ} \mathrm{C} \mathrm{yr}^{-1}$ or more. SND shows a decreasing trend, differ- ent from the trend of the ATI. The maximum SND appeared during the period 1961-1970, while the minimum was found in 2001-2006, in which the decrease of SND was significant over most of the Arctic. In particular, SND over North America has decreased over the wide area since 1991. During 1991-2000, SND decreased by as much as $20 \mathrm{~cm}$ in some 


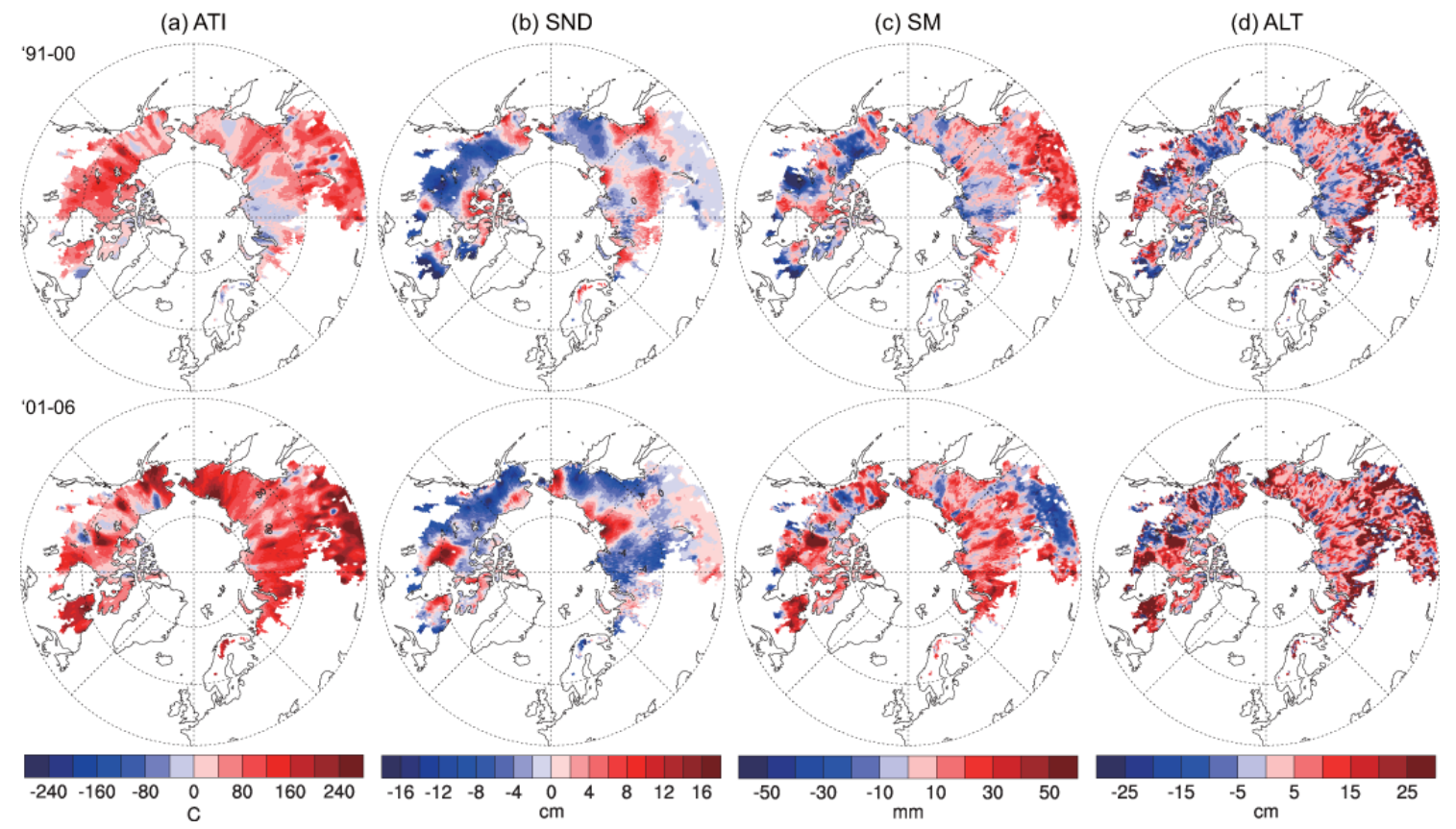

Fig. 4 . Continued.

southern permafrost regions in Canada. Schindler and Donahue (2006) found that, based on observations, maximum snowpack in western Canada decreased $10-33 \mathrm{~cm}$ during the latter half of the 20th century.

Soil moisture exhibits large spatial and temporal variability (Fig. 4c). The Arctic soil of $>60^{\circ} \mathrm{N}$ was considerably moistened during 2001-2006, although some regions of North America experienced drier conditions. SM in the western and eastern regions of Hudson Bay and western Siberia increased above $30 \mathrm{~mm}$ in the same period. ALT also shows large spatial variability (Fig. 4d). However, it generally indicates an increasing trend with years. The significant increase of ALT is found from 1991 onwards and at the boundary regions of permafrost. During 2001-2006, ALT on the Eurasian continent was overall in the positive phase. The region surrounding Hudson Bay showed the most significant increase of ALT, in which it deepened $20 \mathrm{~cm}$ or more. ALT tends to increase with the air temperature warming (Fig. 4a) and soil wetting (Fig. 4c). However, decreases in ALT are also found in the Yukon territory and the Mackenzie watershed.

Time series of mean ALT in the five major Arctic watersheds are shown in Fig. 5. The trends of the ALT time series differ between the Eurasian and North American watersheds. In the three Eurasian watersheds, ALT shows positive trends during 1948-2006 at a statistically significant level in the $\mathrm{Ob}$ and Lena basins (Table 1). ALT of the three Eurasian watersheds had recorded the largest decreases by the early 1970s: $0.40 \mathrm{~m}, 0.50 \mathrm{~m}$, and $0.14 \mathrm{~m}$ in Ob, Yenisey, and Lena, respectively. Thereafter, ALT increased.
The ALT of the three Eurasian watersheds has similar interannual variability to ALT estimated from the thawing index by Zhang et al. (2005). Zhang et al. (2005) reported that in the Lena watershed, changes in ALT based on the thawing index and a numerical model were $0.10 \mathrm{~m}$ and $0.08 \mathrm{~m}$, respectively, over the period of 1980-2002. The corresponding value from CHANGE was $0.094 \mathrm{~m}$. For the period of 1948-2006, CHANGE estimated an ALT increase of $0.12 \mathrm{~m}$ in the Lena. Zhang et al. (2005) found that, based on soil temperature measurements of 17 stations, ALT increased about $0.32 \mathrm{~m}$ between 1956 and 1990 in the Lena.

No obvious trends are seen in the overall (1948-2006) time series of ALT in the two basins of North America (Table 1). However, ALTs in the two North American watersheds show similar fluctuations (Fig. 5d-e). Over the period of 1948-1995, ALT in the Mackenzie increased by about $0.10 \mathrm{~m}(r=0.36, p<0.012)$. The corresponding value in the Yukon was about $0.08 \mathrm{~m}(r=0.37, p<0.009)$. Since 1995, ALTs of the two basins of North America abruptly have decreased, showing the largest decreases in 1996: $0.20 \mathrm{~m}$ and $0.17 \mathrm{~m}$ in the Yukon and Mackenzie, respectively. The negative anomaly lasted into the early 2000s. During the period 1991-2006, the ATI increased (Fig. 4a), as mentioned previously. This implies that other variables, not the air temperature, contributed to the negative ALTs. We will revisit this point later.

\subsection{Variables affecting to ALT anomaly}

Soil thermal states integrate a number of complex interactions between soil, vegetation, snow, and hydrology 
Table 1. Mean, standard deviation (Std.), and trend of active-layer thickness (ALT), annual thawing index (ATI), summer (June-August) soil moisture (SM) excluding ice amount within the soil depth $1.6 \mathrm{~m}$, and snow depth (SND) averaged during January-March in the permafrost region within each watershed.

\begin{tabular}{lrrr|rrr|rrr|rrr}
\hline & \multicolumn{3}{c|}{ ALT } & \multicolumn{3}{c|}{ ATI } & & SM & \multicolumn{3}{c}{ SND } \\
\cline { 2 - 12 } & $\begin{array}{r}\text { Mean } \\
(\mathrm{m})\end{array}$ & $\begin{array}{r}\text { Std. } \\
(\mathrm{m})\end{array}$ & $\begin{array}{r}\text { Trend } \\
\left(\mathrm{m} \mathrm{yr}^{-1}\right)\end{array}$ & $\begin{array}{r}\text { Mean } \\
\left({ }^{\circ} \mathrm{C} \mathrm{yr}^{-1}\right)\end{array}$ & $\begin{array}{r}\text { Std. } \\
\left({ }^{\circ} \mathrm{C}\right)\end{array}$ & $\begin{array}{r}\text { Trend } \\
\left({ }^{\circ} \mathrm{C} \mathrm{yr}^{-1}\right)\end{array}$ & $\begin{array}{r}\text { Mean } \\
(\mathrm{mm})\end{array}$ & $\begin{array}{r}\text { Std. } \\
(\mathrm{mm})\end{array}$ & $\begin{array}{r}\text { Trend } \\
(\mathrm{mm})\end{array}$ & $\begin{array}{r}\text { Mean } \\
(\mathrm{cm})\end{array}$ & $\begin{array}{r}\text { Std. } \\
(\mathrm{cm})\end{array}$ & $\begin{array}{r}\text { Trend } \\
\left(\mathrm{cm} \mathrm{yr}^{-1}\right)\end{array}$ \\
\hline Ob & 2.27 & 0.230 & $0.0046^{\mathrm{a}}$ & 1637.4 & 128.8 & 1.18 & 513.6 & 20.8 & 0.10 & 37.4 & 6.5 & 0.07 \\
Yenisey & 2.68 & 0.131 & 0.0019 & 1429.7 & 86.6 & $2.78^{\mathrm{c}}$ & 510.8 & 11.0 & 0.10 & 40.7 & 5.2 & -0.03 \\
Lena & 1.89 & 0.074 & $0.0020^{\mathrm{c}}$ & 1391.5 & 86.7 & $1.80^{\mathrm{a}}$ & 490.3 & 14.0 & 0.25 & 34.8 & 3.5 & 0 \\
Yukon & 1.57 & 0.072 & 0.0002 & 1277.2 & 107.2 & $2.70^{\mathrm{c}}$ & 434.3 & 18.3 & -0.16 & 29.9 & 8.1 & $-0.20^{\mathrm{b}}$ \\
Mackenzie & 2.01 & 0.083 & 0.0003 & 1502.5 & 123.6 & $3.14^{\mathrm{c}}$ & 472.5 & 14.9 & 0.09 & 32.6 & 7.1 & $-0.23^{\mathrm{c}}$ \\
\hline
\end{tabular}

a Significant at $90 \%$ confidence level by Student's $t$ test,

b $95 \%$ confidence level,

c $99 \%$ confidence level.

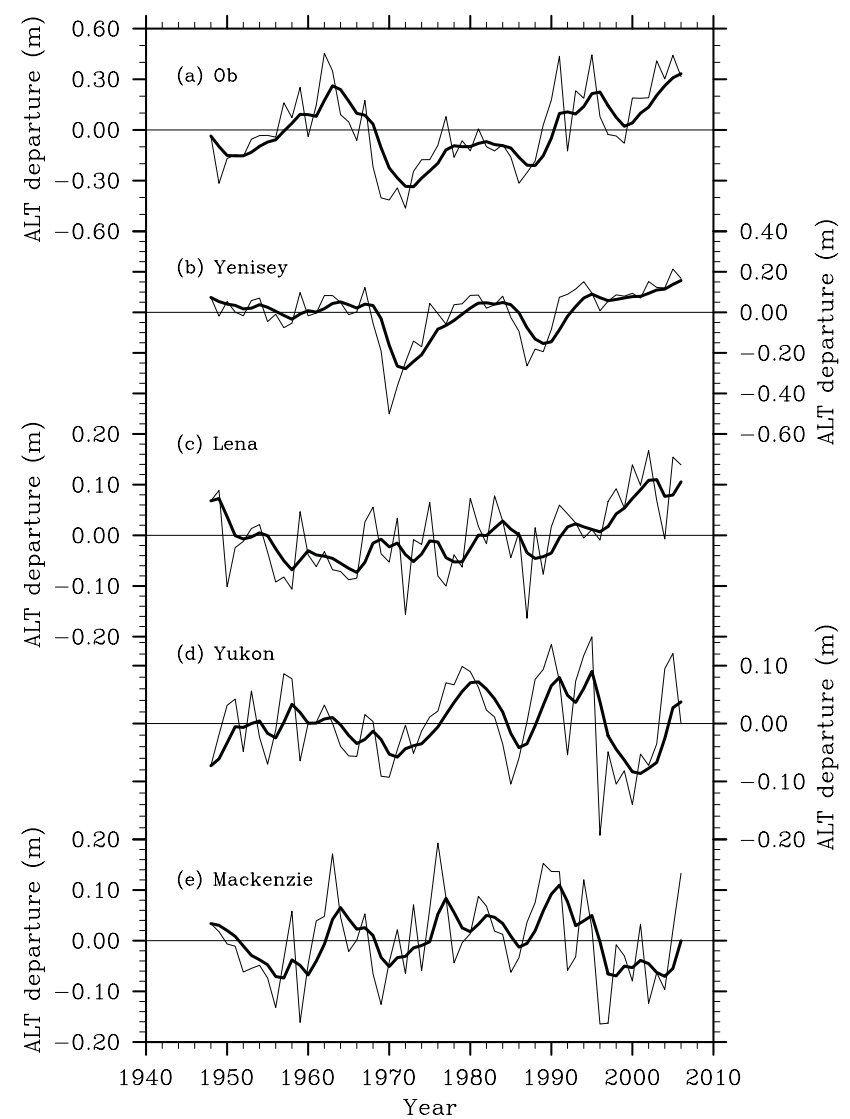

Fig. 5 . Interannual variations of active-layer thickness anomaliess in the major Arctic watersheds: (a) Ob, (b) Yenisey, (c) Lena, (d) Yukon and (e) Mackenzie. The thin lines show the raw data for each watershed, and the thick lines show the values smoothed by a low-pass filter.

(Hinzman et al., 1995; Zhang et al., 1997). Therefore, changes in these factors can influence soil temperature and ALT. The regression map between the detrended ATI anomaly and ALT reveals that ALT responded positively to the ATI in most of the regions (Fig. 6a). The dependence of ALT on the ATI was especially high in northeastern Canada and western Siberia. Surprisingly, the detrended ATI and ALT were not significantly correlated in northwestern North America, even though it is widely believed that a primary control on ALT is the ATI (Romanovsky and Osterkamp, 1995; Zhang et al., 1997). However, ALT regresses more strongly on the detrended SM anomaly over a wide region of the Arctic (Fig. 6b). Interestingly, the regression displays higher values over regions where the mean ALT is generally less than $1.6 \mathrm{~m}$ (Fig. 1a). When ALT increases, the melted ice is added as soil water, thereby increasing SM that in turn contributes to higher ALT. The regression likely represents SM variations implicated in the formation of ALT. Longer observations around Yakutsk, eastern Siberia indicated that soil temperature was positively related to the variation of soil moisture, regardless of vegetation and soil type (Ohta et al., 2008; Iijima et al., 2010). Snow is a strong insulator of the ground, substantially influencing the ground thermal regime (Stieglitz et al., 2003; Zhang, 2005). The area of statistically significant regression of ALT onto the SND accounted for approximately $13 \%$ of the permafrost area (Fig. 6c). For comparison with later results, it should be emphasized that Fig. 6 is for the entire period, 1948-2006.

Figure 6 indicates that ALT has not only responded primarily to the warming trend of air temperature, but also exhibits complex and inconsistent responses to variations in SM and SND. For further discussion on how climate and hydrological variables affect ALT anomalies at interannual time series, two basins (i.e., Lena and Mackenzie) showing different ALT anomalies (Fig. 4c and e) were selected. Figure 7 shows time series of ATI, SM, and SND in the Lena and Mackenzie basins. The ATI in the two basins shows a general increasing trend from the late 1950s, and reached a maximum around 2000 (Fig. 7a). The ATI clearly indicates that the two basins have experienced warming in the summer season since 1980. The magnitude of the increase was larger in the Mackenzie than in the Lena (Table 1). The warming trend 
(a)

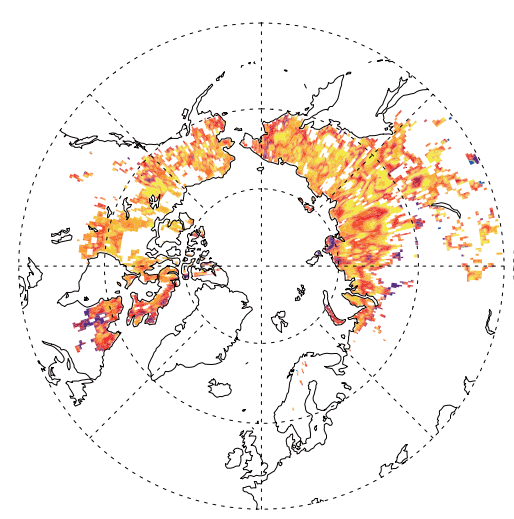

(b)

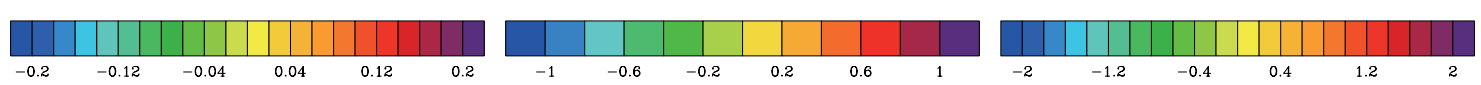

Fig. 6 . Linear regression of active-layer thickness on the detrended annual thawing index $\left(\mathrm{cm}^{\circ} \mathrm{C}^{-1} \mathrm{yr}^{-1}\right)(\mathbf{a})$, soil moisture $\left(\mathrm{cm} \mathrm{mm}{ }^{-1}\right)(\mathbf{b})$, and snow depth $\left(\mathrm{cm} \mathrm{cm}^{-1}\right)$ (c) anomalies for the study period of 1948-2006. The definition of SM is the same as in Fig. 4. The maps display correlations exceeding the $95 \%$ confidence level.

of the ATI was statistically significant in the remaining basins except for the $\mathrm{Ob}$ (Table 1). SM in the two basins simultaneously shows the increase of $20 \mathrm{~mm}$ or more in the mid1970s (Fig. 7b). Between the mid-1970s and 1990, SM of the Lena decreased, showing the largest decrease of $40 \mathrm{~mm}$ in 1987. Thereafter, it in turn increased, showing a maximum increase of $35 \mathrm{~mm}$ in 2005. In the Mackenzie, the largest decrease and increase in SM are $40 \mathrm{~mm}$ in 1996 and $30 \mathrm{~mm}$ in 2005 , respectively. No significance was found in the trend of SM in the five basins (Table 1). SND in the Mackenzie exhibited a maximum in 1962, steadily decreased until 1990s, and showed the largest negative anomaly of about $20 \mathrm{~cm}$ in 1998 (Fig. 7c). On the other hand, SND in the Lena shows small year-to-year variability, compared to the significant trend in the Mackenzie (Table 1). Interestingly, a significant difference is found beginning in 1990: SND in the two basins shows opposite anomalies, as is the case with SM (Fig. 7b).

In the two watersheds, the changing relationship between ALT and ATI, SM, and SND was statistically evaluated by $15 \mathrm{yr}$ moving cross correlation (Fig. 7). The relationship between ATI and ALT in the Lena exhibits the highest correlation over the entire period. The correlation in the Mackenzie remained high until 1990. Thereafter, it abruptly declined below the $95 \%$ significance level (Fig. 7d), despite the positive ATI anomalies (Fig. 7a). During the same period, by contrast, the correlation of SND and ALT in the Mackenzie rapidly increased, reaching the $90 \%$ significance level (Fig. 7f). The relationship between SM and ALT in the two basins was significant during the entire period except for the late 1960s in the Mackenzie (Fig. 7e). The influence of SM on ALT in the two basins simultaneously increased from 1990, when the correlation of ATI and ALT decreased (Fig. 7d). The variation in the SM correlation means that the higher SM in the Lena contributed to higher ALT and the converse in the Mackenzie. The correlation between SND and ALT in the Lena steadily increased from 1960, and it has remained in the range of $0.45-0.60$ since 1980 . By contrast, the correlation in the Mackenzie decreased after 1970 and remained approximately zero during the 1980s (Fig. 7f).

Soil moisture is greatly influenced by precipitation. Figure 8 shows time series of summer (June to August) precipitation for the Lena and Mackenzie, exhibiting large interannual variability. Different trends are found for the precipitation, decreasing in the Lena and increasing in the Mackenzie, although the trends are statistically not significant. Precipitation of the Mackenzie since 1970 has been positively anomalous except for the 1990s, while Lena generally has ranged below the average since 1980 . SM tended to respond positively to the precipitation (Fig. 7b). However, the anomaly of precipitation was not simply expressed to be the same anomaly for SM of the two watersheds. SM of the Lena was positively anomalous during the most recent two decades (Fig. 7b), despite the negative anomaly of precipitation (Fig. 8). On the contrary, SM of the Mackenzie indicates negative or normal state (Fig. 7b). Precipitation contributes to reducing soil dryness. On the other hand, larger precipitation cools soil surface and limits heat conduction into the soil, thereby lowering ALT. In reality, summer precipitation was negatively correlated with ALT in both the Lena $(r=-0.24$, $p<0.08)$ and Mackenzie $(r=-0.18, p<0.18)$. Lower ALT decreases the melt of ice, and hence lowers SM.

\section{Discussion}

This paper's major result, obtained from spatially distributed simulations by a land surface model, is that the ALT 

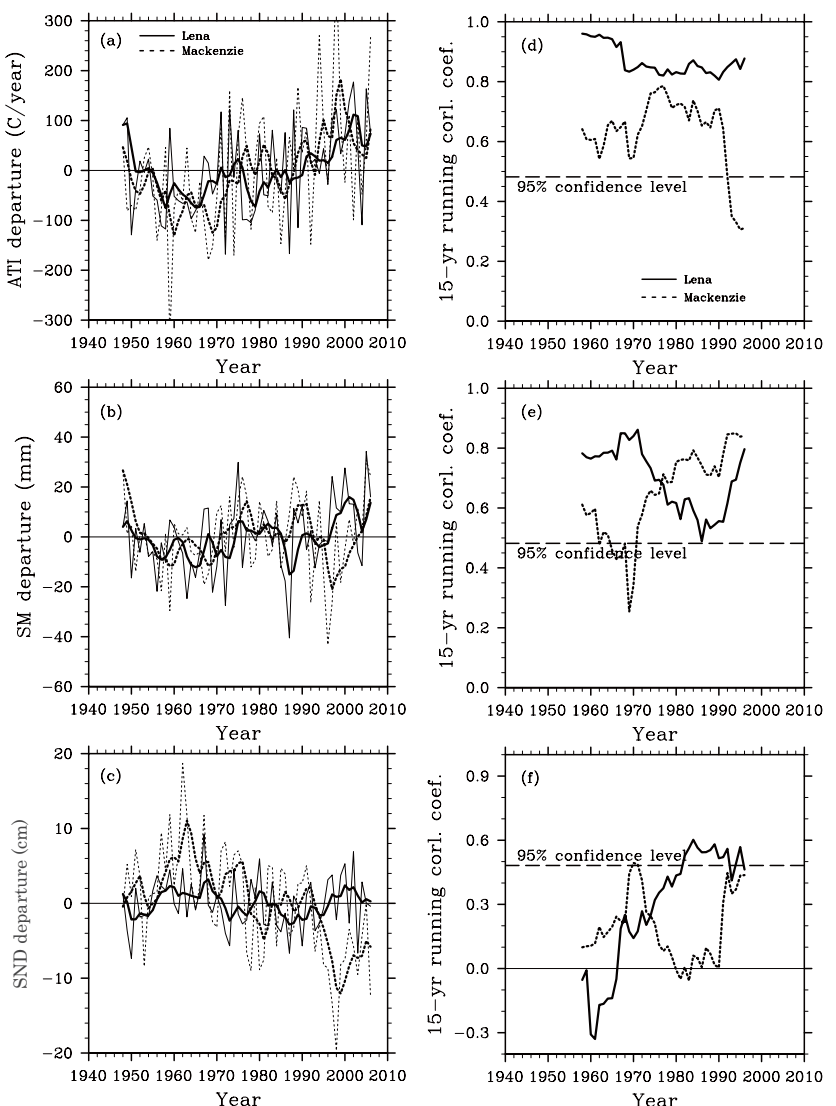

Fig. 7 . Time series of (a) annual thawing index, (b) averaged summer soil moisture during June-August, and (c) mean snow depth during January-March in the Lena and Mackenzie watersheds. Thin and thick lines as in Fig. 5. The $15 \mathrm{yr}$ running correlation coefficients of active-layer thickness against (d) annual thawing index, (e) the summer soil moisture, and (f) the snow depth in the Lena (black) and Mackenzie (red) watersheds. The dashed lines represent $95 \%$ confidence levels.

anomalies differ between the Eurasian and North American basins, especially from 1990 onwards (Fig. 5) when air temperature was significantly warm (Fig. 4a). Variations of the ATI, SM, and SND are indicated to have played a role. However, the responses of ALT to the variables changed in a complex way during the period. A remarkable fact is that the degree of the impact of both SM and SND on ALT was enhanced since 1990. The question remains as to why the roles of SM and SND were heightened during the period. Therefore, we examine the roles of climatic and hydrological variables in the opposition of the ALT anomalies.

Based on snow experiments, Lawrence and Slater (2010) documented that for the recent $50 \mathrm{yr}$ period snow changes explain $50 \%$ or more of the total soil temperature change over much of the terrestrial Arctic. Our statistical analysis, which is for ALT rather than soil temperature, indicates that SND explained as much as $20-30 \%$ of the variance in ALT in the Lena since 1980 and $15-20 \%$ in the Mackenzie since

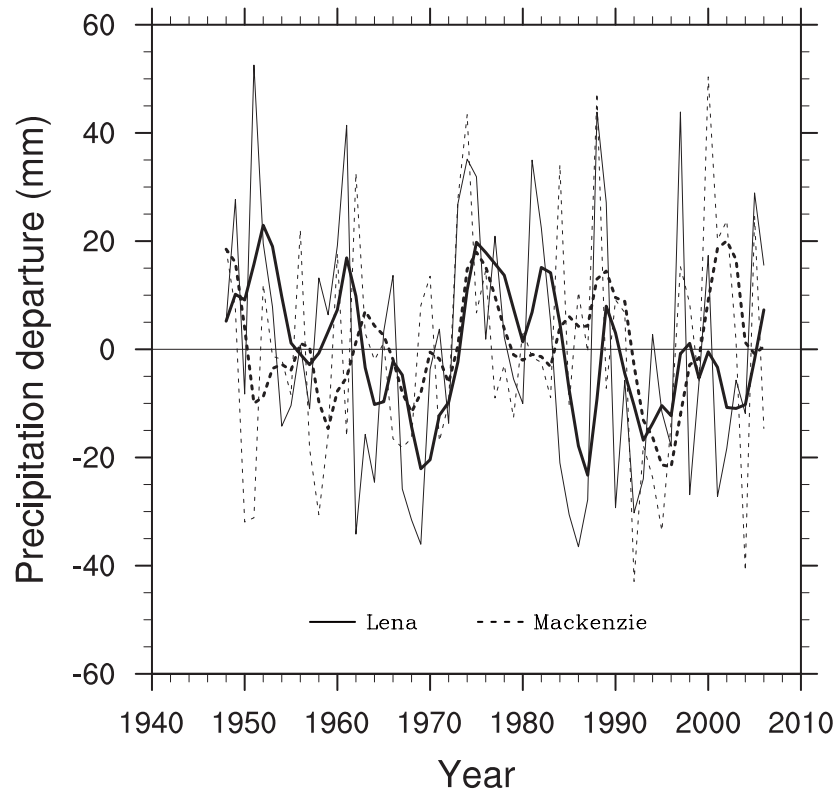

Fig. 8. Interannual precipitation anomaly during the summer season (June-August) over the Lena and Mackenzie watersheds. Thin and thick lines as in Fig. 5.

1990 (Fig. 7f). On the basis of only the percentages, it could be concluded that the influence of SND on ALT was low. However, the influence is never negligible because snow is a strong insulator limiting the efficient communication of heat between the atmosphere and the ground. Based on observations of soil temperature and snow depth from 31 stations in the Russian Arctic, Frauenfeld et al. (2004) found that thicker SND contributed to higher ALT in the following summer. The linear relationship between ALT/soil temperature and SND had also been observed in the interior of Alaska (Brown et al., 2000) and in northern Russia (Pavlov and Moskalenko, 2002). The magnitude of the insulation, which is dependent upon the timing and duration of snow cover and its accumulation and melting history, likely persists to the following summer as a memory in the soil system. In particular, the initial snow state in the early winter is very important to soil temperature (Iijima et al., 2010). Figure 9 investigates the insulation effect of SND on soil temperature, showing the anomaly of the averaged air temperature, SND, and soil temperature at soil depth $1 \mathrm{~m}$ during October to December of 1991-2006. Air temperature over the Arctic during the period was overall warmer. The warming was significant over the Canadian region, which was as much as $2{ }^{\circ} \mathrm{C}$ warmer than preceding decades (Fig. 9a). In spite of the warming, the most significant cooling in soil temperature is found in the Yukon and Mackenzie basins and in the northern region of the Yenisey (Fig. 9c). The maximum cooling of about $2.5^{\circ} \mathrm{C}$ is found in northeastern Alaska. The regions of negative soil temperature anomalies also show negative anomalies in SND (Fig. 9b). This indicates that the 
(a)

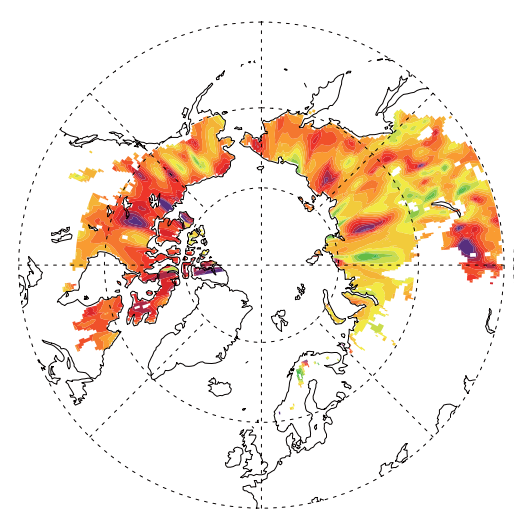

(b)

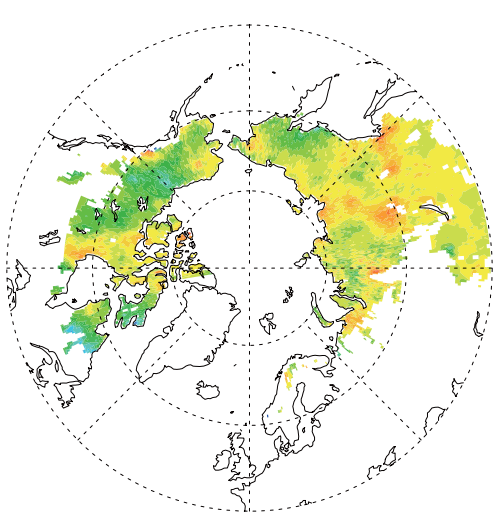

(c)
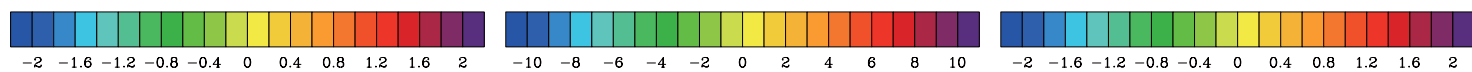

Fig. 9. The anomalous maps of the averaged air temperature $\left({ }^{\circ} \mathrm{C}\right)(\mathbf{a})$, snow depth $(\mathrm{cm})(\mathbf{b})$, and soil temperature at soil depth $1 \mathrm{~m}\left({ }^{\circ} \mathrm{C}\right)(\mathbf{c})$ in the early winter season (October-December) during the period of 1991-2000.

soil cooling was associated with the shallower SND due to weaker winter insulation. Simulations for the 21st-century climate by 20 GCMs show that the increased air temperature will cause both earlier spring snowmelt and a delay in autumnal snow onset (Räisänen, 2008). The late snow accumulation could lead to cooler soil temperature since the lack of snow cover provides less insulation from the cold autumnal air temperature (Lawrence et al., 2010).

It is widely agreed that the principal control on soil temperature is air temperature. In the early winter season, SND in the eastern region of Hudson Bay decreased about 2-8 cm during 1991-2006 (Fig. 9b). However, soil temperature at the region warmed (Fig. 9c), which seems to be associated with higher air temperature (Fig. 9a). Although the thinner SND favors a cooling of the soil, this cooling could be offset by the following summer's higher air temperature. During the period 2001-2006, when SND was anomalously negative over the wide area of the Arctic (Fig. 4b), ALT deepened in all regions except some parts of North America (Fig. 4d) due to the higher ATI (Fig. 4a). It has been documented that ALT depends largely on the thermal history of the ground surface forcing during the thaw period (Romanovsky and Osterkamp, 1997; Zhang et al., 1997). Recent decades have seen large rises in surface air temperature over the Arctic regions (Chapman and Walsh, 2007), but this warming has been less in summer than in winter and spring (Serreze et al., 2000). One might expect that the warming could foster deeper ALT in the Arctic. In reality, the warming ATI accounts for $65-95 \%$ of the variance in ALT in the Lena (Fig. 7a), but much less in the Mackenzie, especially since 1990 (Fig. 7d).

One possible control that can account for the thinner ALT in the Yukon and Mackenzie basins in the recent decades is the impact of the reduced soil moisture (Fig. 7b). In the
Mackenzie, SM has been a primary control on ALT, explaining approximately $50-75 \%$ of the variance in ALT since 1980 (Fig. 7e). In reference, the explanation of SM in the Yukon was approximately 50-90\%. A shallower snow pack could result in lower soil moisture levels in spring. The dry soil has lower thermal conductivity, allowing surface energy to penetrate the soil less effectively, thereby lowering ALT (Fan et al., 2011). However, larger precipitation during the summer season can alleviate the soil dryness caused by the thinner SND. Summer precipitation in the Mackenzie during 2000 to 2002 increased 25-50 mm (Fig. 8), resulting in approximately normal states of SM (Fig. 7b). By contrast, precipitation in the Lena during the same period decreased (Fig. 8). However, SM was higher (Fig. 7b), apparently in association with higher SND (Fig. 7c). Hinkel et al. (2001) found that the infiltration of melted snow water into soil layers caused rapid warming of the upper soil in spring. Soil moisture in the upper-soil layer during the thawing period has measurable impact on ALT, which increases significantly with increasing soil moisture content (Zhang and Stamnes, 1998; Fan et al., 2011). The deepened ALT likely thaws icerich permafrost near the permafrost table, forming a saturated surface and deforming the surface. In reality, the surface deformation caused by the deepened ALT has only been found in Siberia (Iijima et al., 2010) and on the North Slope of Alaska (Liu et al., 2010, 2012).

In summary, the higher ALT in the Lena since 1990 was a combined result of the higher ATI, SND, and SM. While the ATI in the Mackenzie during the same period was higher, this did not result in higher ALT due to both the thinner SND and drier SM. This opposition of ALT anomalies between the two basins highlights increased importance of the variability of hydrological variables. Most climate models project both Arctic warming and increased precipitation in all seasons in 
the 21st century. The summer warming may impact ALT positively. Increased winter precipitation may yield increased snowfall. Callaghan et al. (2011) addressed that, based on six model-projected results using the IPCC A2 emissions scenario, the maximum monthly snow water equivalent for the 2049-2060 period versus 1970-1999 increased 0-15\% over much of the Arctic, with the largest increases (15$30 \%$ ) over the Siberian sector. However, the warmer temperature could cause late autumnal snow accumulation, midwinter snowmelt, and earlier snowmelt in spring. Changes in these snow conditions could influence the soil thermal state during the snow season as well as SM in spring and subsequently ALT. Therefore, when the various likely changes of hydrological processes during the 21 st century are considered together, the possibility that anomalies of ALT may be influenced more by changes in the hydrological variables rather than by the expected overall warming cannot be excluded. A more quantitative view of the expected changes in the hydrology-ALT relationships requires more systematic model experiments and observational data synthesis.

\section{Conclusion}

This study has assessed changes in the spatiotemporal variability of ALT over the Arctic during the period of 19482006, based on observational data and a simulation by a land surface model. The model generally simulated well the spatial distribution of permafrost extent and soil temperature and ALT when compared with point-scale observations. The simulation has also identified contrasting anomalies of ALT between Eurasian and North American basins. The anomalies were the result of the combined impacts of climate and hydrological variables. ALT in the Lena correlated highly with ATI over the study period. However, the warming air temperature was not directly associated with ALT deepening in the Mackenzie basin; since 1990, the correlation of ALT and ATI has significantly decreased, while the influence of SM and SND relatively increased. The shallower SND during the snow season has impeded soil warming due to weaker winter insulation from cold atmospheric air. The soil dryness during the summer season has also limited soil warming, thereby lowering ALT in the Mackenzie. On the other hand, in the Lena basin the warming air temperature together with higher SND and SM for the most recent $30 \mathrm{yr}$ has promoted the increase in ALT.

Larger precipitation can offset the soil dryness associated with the shallower SND. In contrast, the larger precipitation during summer cools the soil surface and limits heat conduction into the soil. Indeed, summer total precipitation tended to have a negative correlation with ALT in the Lena and Mackenzie basins. This implies that the larger summer precipitation weakened atmospheric thermal forcing, and hence lowered ALT.
The ALT anomalies of opposite sign in the Lena and Mackenzie basins appeared even when the air temperature showed overall warming. The modeling described here also illustrates the complex variability of regional SND, including variations that are inconsistent with the Arctic warming trend. This suggests that the response of permafrost to snow could be important under a future Arctic warming. The dependence of precipitation/snow on atmospheric weather patterns increases the uncertainty in the magnitude or amplitude of the future snow changes. Future snow changes have the potential to either amplify or dampen the expression of climate warming below the ground surface and its subsequent impacts on permafrost distribution as well as ecological and biogeochemical processes in the Arctic.

Acknowledgements. A part of this study was supported as a collaboration theme between JAMSTEC and International Arctic Research Center (IARC), University of Alaska, Fairbanks.

Edited by: T. Zhang

\section{References}

Alexeev, V. A., Nicolsky, D. J., Romanovsky, V. E., and Lawrence, D. M.: An evaluation of deep soil configurations in the CLM3 for improved representation of permafrost, Geophys. Res. Lett., 34, L09502, doi:10.1029/2007GL029536, 2007.

Anisimov, O. A. and Nelson, F. E.: Permafrost zonation and climate change in the Northern Hemisphere: Results from transient general circulation models, Climatic Change, 35, 24-258, doi:10.1023/A:1005315409698, 1997.

Bekryaev, R. V., Polyakov, I. V., and Alexeev, V. A.: Role of polar amplification in long-term surface air temperature variations and modern Arctic warming, J. Climate, 23, 3888-3906, doi:10.1175/2010JCLI3297.1, 2010.

Biancamaria, S., Cazenave, A., Mognard, N. M., Llovel, W., and Frappart F.: Satellite-based high latitude snow volume trend, variability and contribution to sea level over 1989/2006, Global Planet. Change, 75, 99-107, doi:10.1016/j.gloplacha.2010.10.011, 2011.

Brown, J., Hinkel, K. M., and Nelson, F. E.: The Circumpolar Active Layer Monitoring (CALM) Program: Research designs and initial results, Polar Geography, 24, 165-258, 2000.

Brown, J., Ferrians, O. J., Heginbottom, J. A., and Melnikov, E. S.: Circum-Arctic map of permafrost and ground-ice conditions, National Snow and Ice Data Center/World Data Center for Glaciology, Boulder, CO, Digital Media, available at: http://nsidc.org, 2001.

Brown, R., Derksen, C., and Wang, L.: A multi-data set analysis of variability and change in Arctic spring snow cover extent, 1967-2008, J. Geophys. Res., 115, D16111, doi:10.1029/2010JD013975, 2010.

Bulygina, O., Razuvaev, V., and Korshunova, N.: Change in snow cover northern Eurasia in the last decades, Environ. Res. Lett., 4, 045026, doi:10.1088/17489326/14/4/045026, 2009.

Callaghan, T. V., Johansson, M., Brown, R. D., Groisman, P. Y., Labba, N., and Radionov, V.: Changing snow cover and its im- 
pacts, in AMAP, 2011, Snow, Water, Ice and Permafrost in the Arctic (SWIPA): Climate Change and the Cryosphere, Arctic Monitoring and Assessment Programme (AMAP), Oslo, Norway, 538 pp., 2011.

Castellví, F., Perez, P., Villar, J., and Resell, J.: Analaysis of methods for estimating vapor pressure deficits and relative humidity, Agr. Forest Meteorol., 82, 29-45, 1996.

Chapman, W. L. and Walsh, J. E.: Simulations of Arctic temperature and pressure by global coupled models, J. Climate, 20, 609-632, doi:10.1175/JCLI4026.1, 2007.

Chen, W., Zhang, Y., Cihlar, J., Smith, S. L., and Riseborough, D. W.: Changes in soil temperature and active-layer thickness during the twentieth century in western Canada, J. Geophys. Res., 108, 4696, doi:10.1029/2002JD003355, 2003.

Dankers, R., Burke, E. J., and Price, J.: Simulation of permafrost and seasonal thaw depth in the JULES land surface scheme, The Cryosphere, 5, 773-790, doi:10.5194/tc-5-773-2011, 2011.

Dyer, J. L. and Mote, T. L.: Spatial variability and trends in observed snow depth over North America, Geophys. Res. Lett., 33, L16503, doi:10.1029/2006GL027258, 2006.

Fan, Z. S., Neff, J. C., Harden, J. W., Zhang, T., Veldhuis, H., Czimczik, C. I., Winston, G. C., and O'Donnell, J. A.: Water and heat transport in boreal soils: Implications for soil response to climate change, Sci. Total Environ., 409, 1836-1842, doi:10.1016/j.scitotenv.2011.02.009, 2011.

Frauenfeld, O. W., Zhang, T., Barry, R. G., and Gilichinsky, D.: Interdecadal changes in seasonal freeze and thaw depths in Russia, J. Geophys. Res., 109, D05101, doi:10.1029/2003JD004245, 2004.

Global Soil Data Task: Global Soil Data Products CD-ROM (IGBP-DIS), CD-ROM, International Geosphere-Biosphere Programme, Data and Information System, Potsdam, Germany. Available from Oak Ridge National Laboratory Distributed Active Archive Center, Oak Ridge, Tennessee, USA, 2000.

Hinkel, K. M., Paetzold, R. F., Nelson, F. E., and Bockheim, J. G.: Patterns of soil temperature and moisture in the active layer and upper permafrost at Barrow, Alaska: 1993-1999, Global Planet. Change, 29, 293-309, 2001.

Hinzman, L. D., Goering, D. G., Kinney, T. C., and Li, S.: Numerical simulation of thermokarst formation during disturbance, in: Proceedings of a Intl. Workshop on Disturbance and Recovery of Arctic Terrestrial Ecosystems, Arctic Centre, Univ. of Lapland, Rovaniemi, Finland, 1995.

Hirabayashi, Y., Kanae, S., Struthers, I., and Oki, T.: A 100-year (1901-2000) global retrospective estimation of terrestrial water cycle, J. Geophys. Res., 110, D19101, doi:10.1029/2004JD005492, 2005.

Hirabayashi, Y., Kanae, S., Motoya, K., Masuda, K., and Doll, P.: A 59-year (1948-2006) global near-surface meteorological data set for land surface models. Part I: Development of daily forcing and assessment of precipitation intensity, Hydrol. Res. Lett., 2, 36-40, 2008.

Iijima, Y., Fedorov, A. N., Park, H., Suzuki, K., Yabuki, H., Maximov, T. C., and Ohata, T.: Abrupt increases in soil temperatures following increased precipitation in a permafrost region, central Lena river basin, Russia, Permafrost Periglac., 21, 30-41, doi:10.1002/ppp.662, 2010.

Intergovernmental Panel of Climate Change (IPCC), Climate Change 2007: Synthesis Report. Contribution of Working
Groups I, II and III to the Fourth Assessment Report of the Intergovernmental Panel on Climate Change, edited by Core Writing Team and Solomon, S., Qin, D., Manning, M., Chen, Z., Marquis, M., Averyt, K. B., Tignor, M., and Miller, H. L., 104 pp., Geneva, Switzerland, 2008.

Lachenbruch, A. H. and Marshall, B. V.: Changing climate: Geothermal evidence from permafrost in the Alaskan Arctic, Science, 234, 689-696, 1986.

Lawrence, D. M. and Slater, A. G.: The contribution of snow condition trends to future ground climate, Clim. Dynam., 34, 969-981, doi:10.1007/s00382-009-0537-4, 2010.

Lawrence, D. M., Slater, A. G., Romanovsk, V. E., and Nicolsky, D. J.: The sensitivity of a model projection of nearsurface permafrost degradation to soil column depth and inclusion of soil organic matter, J. Geophys. Res., 113, F02011, doi:10.1029/2007JF000883, 2008.

Lawrence, D. M., Slater, A. G., and Swenson, S. C.: Simulation of present-day and future permafrost and seasonally frozen ground conditions in CCSM4, J. Climate, 25, 2207-2225, doi:10.1175/JCLI-D-11-00334.1, 2011.

Liu, L., Zhang, T., and Wahr, J.: InSAR measurements of surface deformation over permafrost on the North Slope of Alaska, J. Geophys. Res., 115, F03023, doi:10.1029/2009JF001547, 2010.

Liu, L., Schaefer, K., Zhang, T., and Wahr, J.: Estimating 1992 2000 average active layer thickness on the Alaskan North Slope from remotely sensed surface subsidence, J. Geophys. Res., 117, F01005, doi:10.1029/2011JF002041, 2012.

McGuire, A. D., Chapin, F. S., Walsh, J. E., and Wirth, C.: Integrated regional changes in Arctic climate feedbacks: Implications for the global climate system, Ann. Rev. Env. Resour., 31, 61-91, doi:10.1146/annurev.energy.31.020105.100253, 2006.

Meador, W. and Weaver, W.: Two-stream approximations to radiative transfer in planetary atmospheres: A unified description of existing methods and a new improvement, J. Atmos. Sci., 37, 630-643, 1980.

Mölders, N. and Romanovsky, V. E.: Long-term evaluation of the Hydro-Thermodynamics Soil-Vegetation Scheme's frozen ground/permafrost component using observations at Barrow, Alaska, J. Geophys. Res., 111, D04105, doi:10.1029/2005JD005957, 2006.

Oelke, C., Zhang, T., and Serreze, M. C.: Modeling evidence for recent warming of the Arctic soil thermal regime, Geophys. Res. Lett., 31, L07208, doi:10.1029/2003GL019300, 2004.

Ohta, T., Maximov, T. C., Dolman, A. J., Nakai, T., van der Molen, M. K., Kononov, A. V., Maximov, A.P., Hiyama, T., Iijima, Y., Moors, E. J., Tanaka, H., Toba, T., and Yabuki, H.: Interannual variation of water balance and summer evapotranspiration in an eastern Siberian larch forest over a 7-year period (1998-2006), Agr. Forest Meteorol., 148, 1941-1953, doi:10.1016/j.agrformet.2008.04.012, 2008.

Osterkamp, T.: Characteristics of the recent warming of permafrost in Alaska, EOS, 88, 522-523, doi:10.1029/2007EO480002, 2007.

Park, H., Iijima, Y., Yabuki, H., Ohta, T., Walsh, J. E., Kodama, Y., and Ohata, T.: The application of a coupled hydrological and biogeochemical model (CHANGE) for modeling of energy, water, and $\mathrm{CO}_{2}$ exchange over a larch forest in eastern Siberia, J. Geophys. Res., 116, D15102, doi:10.1029/2010JD015386, $2011 \mathrm{a}$. 
Park, H., Yabuki, H., and Ohata, T.: Analysis of satellite and model datasets for variability and trends in Arctic snow extent and depth, 1948-2006, Polar Sci., 6, 23-37, doi:10.1016/j.polar.2011.11.002, 2011b.

Pavolv, A. V. and Moskalenko, N. G.: The thermal regime of soils in the north of western Siberia, Permafrost Periglacial Proc., 13, 43-51, 2002.

Qian, B., Gregorich, E. G., Gameda, S., Hopkins, D. W., and Wang, X. L.: Observed soil temperature trend associated with climate change in Canada, J. Geophys. Res., 116, D02106, doi:10.1029/2010JD015012, 2011.

Räisänen, J.: Warmer climate: less or more snow?, Clim. Dynam., 30, 307-319, doi:10.1007/s00382-007-0289-y, 2008.

Ramankutty, R. and Foley, J. A.: Estimating historical changes in global land cover: Croplands from 1700 to 1992, Global Biogeochem. Cy., 13, 997-1027, 1999.

Romanovsky, V. E. and Osterkamp, T. E.: Interannual variations of the thermal regime of the active layer and near-surface permafrost in Northern Alaska, Permafrost Periglac. Proc. 6, 313335, 1995.

Romanovsky, V. E. and Osterkamp, T. E.: Thawing of the active layer on the coastal plain of the Alaskan Arctic, Permafrost Periglac. Proc., 8, 1-22, doi:10.1002/(SICI)10991530(199701)8:1;1::AID-PPP243;3.0.CO;2-U, 1997.

Romanovsky, V. E., Smith, S. L., and Christiansen, H. H.: Permafrost thermal state in the polar Northern Hemisphere during the International Polar Year 2007-2009: a synthesis, Permafrost Periglac. Proc., 21, doi:10.1002/ppp.689, 2010.

Schindler, D. W. and Donahue, W. F.: An impending water crisis in Canada's western prairie provinces, Proc. Natl. Acad. Sci. USA, 103, 7210-7216, doi:10.1073/pnas.0601568103, 2006.

Screen, J. A. and Simmonds, I.: The central role of diminishing sea ice in recent Arctic temperature amplification, Nature, 464, 1334-1337, doi:10.1038/nature09051, 2010.

Serreze, M. C., Walsh, J. E., Chapin, F. S., Osterkamp, T., Dyurgerov, M., Romanovsky, V. E., Oechel, W. C., Morison, J., Zhang, T., and Barry, R. G.: Observational evidence of recent change in the northern high-latitude environment, Climatic Change, 46, 159-207, 2000.

Smerdon, J. E. and Stieglitz, M.: Simulating heat transport of harmonic temperature signals in the Earth's shallow subsurface: Lower-boundary sensitivities, Geophys. Res. Lett., 33, L14402, doi:10.1029/2006GL026816, 2006.

Smith, S. L., Romanovsky, V. E., Lewkowicz, A. G., Burn, C. R., Allard, M., Clow, G. D., Yoshikawa, K., and Throop, J.: Thermal state of permafrost in North America: A contribution to the International Polar Year, Permafrost Periglac. Proc., 21, doi:10.1002/ppp.690, 2010.

Stevens, M. B., Smerdon, J. E., Gonzalez-Rouco, J. F., Stieglitz, M., and Beltrami, H.: Effects of bottom boundary placement on subsurface heat storage: Implications for climate model simulations, Geophys. Res. Lett., 34, L02702, doi:10.1029/2006GL028546, 2007.
Stieglitz, M., Dery, S. J., Romanovsky, V. E., and Osterkamp, T. E.: The role of snow cover in the warming of Arctic permafrost, Geophys. Res. Lett., 30, 1721, doi:10.1029/2003GL017337, 2003.

Thornton, P. E., Law, B. E., Gholz, H. L., Clark, K. L., Falge, E., Ellsworth, D. S., Goldstein, A. H., Monson, R. K., Hollinger, D., Falk, M., Chen, J., and Sparks, J. P.: Modeling and measuring the effects of disturbance history and climate on carbon and water budgets in evergreen needleleaf forests, Agr. Forest Meteorol., 113, 185-222, 2002.

White, M. A., Thornton, P. E., Running, S. W., and Nemani, R. R.: Parameterization and sensitivity analysis of the BIOME-BGC terrestrial ecosystem model: Net primary production controls, Earth Interact., 4, 1-85, doi:10.1175/10873562(2000)004 ¡0003:PASAOT ¿2.0.CO;2, 2000.

Zhang, T.: Influence of the seasonal snow cover on the ground thermal regime: an overview, Rev. Geophys., 43, RG4002, doi:10.1029/2004RG000157, 2005.

Zhang, T. and Stamnes, K.: Impact of climatic factors on the active layer and permafrost at Barrow, Alaska, Permafrost Periglac. Proc., 9, 229-246, 1998.

Zhang, T., Osterkamp, T. E., and Stamnes, K.: Some characteristics of the climate in northern Alaska, USA, Arct. Alp. Res., 28, 509$518,1996$.

Zhang, T., Osterkamp, T. E., and Stamnes K.: Effects of climate on the active layer and permafrost on the north slope of Alaska, USA, Permafrost Periglac. Proc., 8, 45-67, 1997.

Zhang, T., Barry, R. G., Knowles, K., Heginbottom, J. A., and Brown, J.: Statistics and characteristics of permafrost and ground ice distribution in the Northern Hemisphere, Polar Geography, 23, 147-169, 2008.

Zhang, T., Barry, R. G., Gilichinsky, D., Bykhovets, S. S., Sorokovikov, V. A., and Ye, J.: An amplified signal of climatic change in soil temperatures during the last century at Irkutsk, Russia, Climatic Change, 49, 41-76, 2001.

Zhang, T., Frauenfeld, O. W., Serreze, M. C., Etringer, A., Oelke, C., McCreight, J., Barry, R. G., Gilichinsky, D., Yang, D., Ye, H., Ling, F., and Chudinova, S.: Spatial and temporal variability in active layer thickness over the Russian Arctic drainage basin, J. Geophys. Res., 110, D16101, doi:10.1029/2004JD005642, 2005.

Zhang, Y., Chen, W., Smith, S. L., Riseborough, D. W., and Cihlar, J.: Soil temperature in Canada during the twentieth century: Complex responses to atmospheric climate change, J. Geophys. Res., 110, D03112, doi:10.1029/2004JD004910, 2005. 